\title{
Biology of Blastopsylla occidentalis (Hemiptera: Psylloidea: Aphalaridae), a pest of Eucalyptus globulus (Myrtaceae) in Yaounde, Cameroon
}

\section{Dzokou Victor Joly*}

Department of Crop Protection (UR_PHYZA), Faculty of Agronomy and Agricultural Sciences, University of Dschang, P.O. Box. 222 Dschang, Cameroon

Soufo Laurentine

Department of Biological Sciences, Faculty of Sciences, University of Maroua, P.O. Box. 814 Maroua, Cameroon

Tamesse Joseph Lebel

Department of Biological Sciences, Higher Teachers' Training College, University of Yaounde I, P.O. Box. 47 Yaounde, Cameroon

*Corresponding author. E-mail: dzovijo@yahoo.fr

\begin{abstract}
Eucalyptus spp belong to the family of Myrtaceae and grow all over the world and are adapted to different climates and soils. In Cameroon, these plants are very important for their medicinal and ecological virtues. Eucalyptus globulus has economically and ornamentally values. Blastopsylla occidentalis Taylor (Psylloidea: Aphalaridae) is one of the insects feeding on this plant and its causes severe damages to their host plants. Significant damage occurred in nurseries and in a very young plantations of Eucalyptus spp. The biology of $B$. occidentalis was studied from July 2010 to June 2011 at Yaounde. The parameters mating process, choice of the egg-laying site by the females, fecundity of the females, longevity of the adults, embryonic and larval development, life cycle and sex ratio were studied. The results showed that males emerged before females, and the mating process lasted about 42 minutes. The longevity of adults was 11 days on average and egg-laying began 8 days after emergence. The average fertility was 38 eggs per female. The eggs were laid on the buds, bracts, young leaves and twigs of its host plant. The life cycle, from egg to egg, required 32 days on average. The sex ratio was close to 1.03. This species fed and developed on Eucalyptus spp. has never been observed on other plants species in the study area, suggesting a specificity of this psyllid to its host plant. These results can be considered as an important step for the establishment of integrated pest control against Eucalyptus psyllid pest species in Cameroon.
\end{abstract}

Keywords: Biology, Cameroon, Eucalyptus, Psyllid.

\section{INTRODUCTION}

Psyllids or jumping plant lice belong to the order Hemiptera and super family Psylloidea and are considered as an important pest for their host plants. They attack spontaneous plants and cultivated plants of economic, pharmaceutical, or ornamental importance. The biological study of some psyllids species were carried out on some cultivated plants; the most important one are the work of Bonnemaison and Missonier (1956) studying the biology of Psylla pyri, pear psyllid; Messi (1984), Mesohomotoma tessmanni, cocoa psyllid; Tamesse (1996), Trioza erytreae, citrus psyllid; Teck et al. (2011), Diaphorina citri, citrus psyllid; Goolsby et al. (2012), Bactericera cockerelli, potato psylla; Chireceanu and Fatu (2012), Cacopsylla melanoneura, apples psylla. Psyllids associated on forest species of economic importance have

\section{Article Info}

https://doi.org/

10.31018/jans.v12i1.2220

Received: February 21, 2020

Revised: March 2, 2020

Accepted: March 8, 2020

\section{How to Cite}

Dzokou, V. J. et. al. (2020) Biology of Blastopsylla occidentalis (Hemiptera: Psylloidea: Aphalaridae), a pest of Eucalyptus globulus (Myrtaceae) in Yaounde, Cameroon. Journal of Applied and Natural Science, 12(1): 30 - 35 https://doi.org/10.31018/ jans.v12i1.2220 
Eucalyptus spp. belongs to the plant family of Myrtaceae, originated from Australia and is planted in all regions of the world. They are adapted to different climates and soils. In Cameroon, different eucalyptus plant species are planted in all the agro-ecological zones. They are used as important remedies in the traditional medicine for the treatment of malaria, asthma, urinary and skin diseases, pains of stomach and dysmenorrhea; the plants are also used to remove water from wetlands and, commonly, as materials for construction (Doran and Wongkaeu, 1997). All stage development feed on the sap of eucalyptus plant. They produced necrosis and drop of buds. B. occidentalis may contribute to the degeneracy of the eucalyptus trees throughout the main area of its growing. The aim of this work was to study the biology of this psyllid $B$. occidentalis. The study could provide necessary information to set up an integrated pest management program to control this pest in Cameroon.

\section{MATERIALS AND METHODS}

The study of the biology of $B$. occidentalis was conducted from June $1^{\text {st }}, 2010$ to May $31^{\text {st }}, 2011$ in the campus of the Higher Teachers' Training College of the University of Yaounde I on nursery plants of E. globulus. This study was carried out on the mating process, the choice of the egglaying site by the females, the sex ratio at emergence, the female fertility, the longevity of the adults, the embryonic and larval developments of this pest.

Nursery preparation and infestation: Eucalyptus spp. seedlings were obtained from the western region of Cameroon in a eucalyptus nursery in Bafoussam. Eighty young plants were transplanted and used for this survey. Additional organic fertilizers were added to increase the level of nutrients to the plants. Three months after the transplantation, seedlings were ready for the investigation. These seedlings were infected by specimens of $B$. occidentalis collected on ornemental eucalyptus plants located at Saint Anastasia Park in Yaounde town. No insecticide treatment was applied during the observation period.

Ten seedlings were protected from insect attack by moving them away from other plants. These seedlings were used as a control to study the damages of this insect to the plant. One month later, 20 plants were selected for the first infestations that began on June 1, 2010. The infestation was made using stages 4 and 5 larvae of $B$. occodentalis. The infested plants were protected using white and light cages with $0.01 \mathrm{~mm}$ mesh to avoid adults escaping after last mouth. These adults were isolated in transparent cages at emergence to better observe them. After the fledging, one male and female of the psyllids were isolated on young buds protected with transparent cages

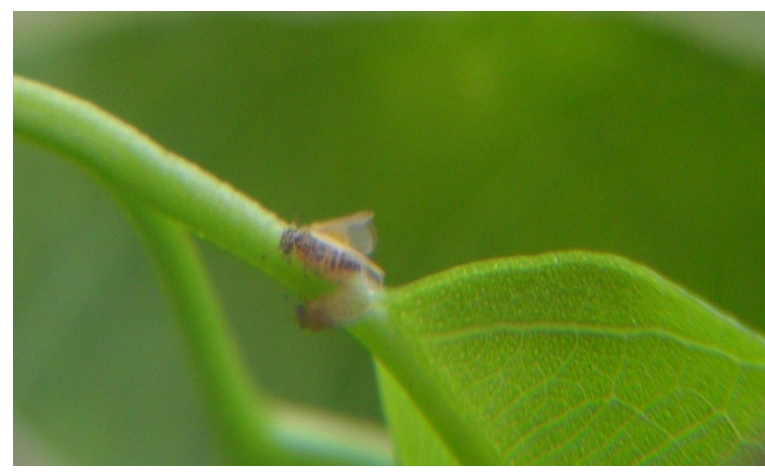

Fig. 1. Mating in B. occidentalis.

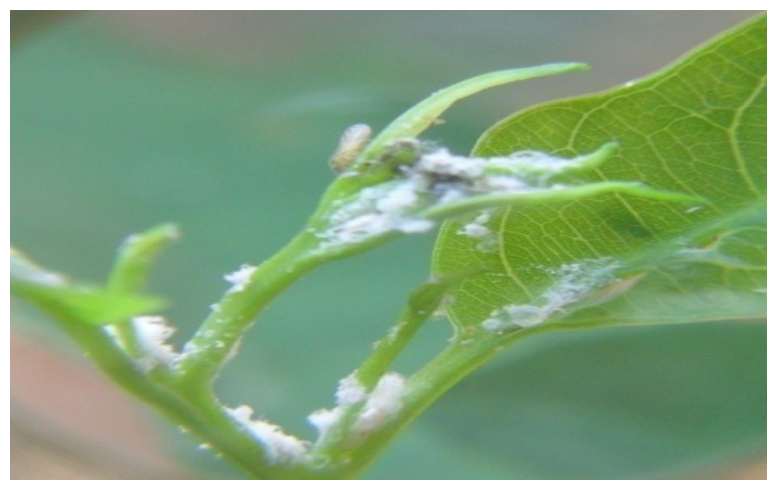

Fig. 2. White wax secretion of $B$. occidentalis on a Eucalyptus bud.

for the study of fertility. Fecundity of females was assessed on 140 couples of $B$. occidentalis by counting the number of eggs laid per day and per female until the death of the female.

Life cycle: The observations were made daily for 6 hours using a hand lens. The number of eggs laid, the number of individuals for each of the five larval stages and adults were counted on each of the experimental plant. The mating procedure was studied by observing newly emerged adults. The duration of the mating was noted and the number of days before laying was also noted. The laying sites choose by female were noted and the number of eggs laid per day per plant was counted. The duration of the development of each larval stage was noted up to the emergence of adults. Adult longevity was evaluated by counting the number of days from egg hatching to the death of adults. The life cycle (egg-eggs) and sex ratio (male / female) of the psyllids were evaluated. The nature of the damages caused by the psyllids on their host was noted.

Parthenogenesis was performed on 68 females of $B$. occidentalis isolated in cages after fledging without mating to observe eggs laying on buds.

\section{RESULTS}

Mating and laying site: During the study of biology of $B$. occidentalis, males emerged before females. Males were more active and are thus being the first to take the initiative of mating, the mating 
Dzokou, V. J. et. al. / J. Appl. \& Nat. Sci. 12(1): 30 - 35 (2020)

Table 1. Summary of the duration (in days) of the different stages of development of $B$. occidentalis, pest of Eucalyptus sp.

\begin{tabular}{llccc}
\hline & & \multicolumn{3}{c}{ Duration stage (days) } \\
\cline { 3 - 5 } Stage & Effectifs & Minimum & Maximum & Average (X SD) \\
\hline Egg & 5107 & 3 & 14 & $10.11 \pm 1.05$ \\
$1^{\text {st }}$ instar & 3630 & 2 & 7 & $3.78 \pm 0.67$ \\
$2^{\text {nd }}$ instar & 2644 & 2 & 7 & $3.67 \pm 0.50$ \\
$3^{\text {rd }}$ instar & 2141 & 2 & 8 & $3.56 \pm 0.53$ \\
$4^{\text {th }}$ instar & 1774 & 2 & 7 & $4.0 \pm 0.71$ \\
$5^{\text {th }}$ instar & 1580 & 2 & 11 & $4.67 \pm 1.22$ \\
Life cycle (egg-egg) & 9 & 27 & 40 & $31.78 \pm 3.73$ \\
Fecundity & & 22 & 50 & $37.13 \pm 8.62$ \\
Female longevity & 549 & 3 & 31 & $10.44 \pm 2.07$ \\
Male longevity & 612 & 3 & 34 & $10.33 \pm 2.35$ \\
Time before mating & & 2 & 11 & $5.33 \pm 1.32$ \\
Time before laying & & 4 & 17 & $5.33 \pm 1.32$ \\
Sex-ratio (male/female) & & 0.7 & 1.58 & $1.03 \pm 0.33$ \\
\hline
\end{tabular}

Table 2. Summary of the survival rate of the different stages of development of $B$. occidentalis, pest of Eucalyptus sp.

\begin{tabular}{llll}
\hline \multirow{2}{*}{ Stage } & \multicolumn{2}{c}{ Survival rate (\%) } \\
\cline { 2 - 4 } & Minimum & Maximum & Average (X土 SD) \\
\hline Egg & 45.2 & 88.6 & $67.48 \pm 13.77$ \\
$1^{\text {st }}$ instar & 40.9 & 89.9 & $69.2 \pm 15.97$ \\
$2^{\text {nd }}$ instar & 41.1 & 96.2 & $73.22 \pm 21.65$ \\
$3^{\text {rd }}$ instar & 52.9 & 95.2 & $79.43 \pm 15.60$ \\
$4^{\text {th }}$ instar & 68.4 & 97.7 & $86.54 \pm 9.52$ \\
$5^{\text {th }}$ instar & 53.9 & 89.8 & $74.19 \pm 13.56$ \\
\hline
\end{tabular}

process take about 42 minutes on average. During mating, the male approaches the female with its antennae oriented towards it. It straddles the female and joins its genitalia with the one of the female. The male rotate laterally and the couple forms an acute angle (Figure 1). Few minutes later, the female turn over and the couple forms an angle of $180^{\circ}$ while remaining connected within their genitalia. This mating position lasts from four minutes to one hour. At the end of the mating, female starts checking to be free and the couple separates just after. A female could mate several times before and during the eggs laying period. After fledging, the mean time to start mating was $5.33 \pm 1.32$ days with a minimum of 2 days and a maximum of 7 days. After fledging, the mean time before the egg laying was $7.67 \pm 1.5$ days with a minimum of 5 days and a maximum of 12 days.

After mating, females of $B$. occidentalis lay eggs on buds, young leaves, bracts and young twigs. The preferred spawning site was the bud. On young leaves, eggs were deposited on the upper surface at the level of the main vein and the edges of the leaf.

Adult longevity and fertility of females: The longevity of an insect is the time that this insect flies until it dies. The fertility of a female is the average number of eggs that a female can lay. Mean longevity of the female was estimated to $10.44 \pm 2.07$ days and that of the male was 10.33 \pm 2.35 days with a minimum of 3 days and a maximum of 23 days for females and 22 days for males. Females and males of $B$. occidentalis have almost the same longevity.

The fecundity was $37.13 \pm 8.62$ eggs on average per female with a minimum value of 22 eggs and a maximum value of 50 eggs per female. Parthenogenesis reproduction did not occur for $B$. occidentalis; none of the 68 females surveyed without mating, in absence of male, laid eggs.

Life cycle: The life cycle of the psyllids included the following developmental stages: eggs, larval stages and adults. Observations made during this study showed that the total development of $B$. occidentalis lasts 27 to 40 days with an average of $31.78 \pm 3.73$ days (Table 1 ). The embryonic development lasts $10.11 \pm 1.05$ days on average with a minimum of 5 days and a maximum of 13 days. Larval stage I developed within 3 to 6 days and $3.78 \pm 0.67$ days on average to become larval stage II. The later one developed within 3 to 6 days and $3.67 \pm 0.50$ days on average to become larval stage III. The larval stage III developed within 3 to 6 days and $3.56 \pm 0.53$ days on average to become larval stage IV. Lastly, the larval stage VI developed within 3 to 7 days and $4.0 \pm 0.71$ days on average to become larval stage $\mathrm{V}$. The last moult of the $5^{\text {th }}$ instar larvae occurs after 3 to 8 days, with $4.67 \pm 1.22$ days on average.

The survival rate of the various larval stages (Table 2) of the eucalypts psyllid was $67.48 \pm$ $13.77 \%$; $69.2 \pm 15.97 \%$, $73.22 \pm 21.65 \%, 79.43 \pm$ $15.60 \%, 86.54 \pm 9.52 \%$ and $74.19 \pm 13.56 \%$ respectively for the eggs, $1^{\text {st }}$ to the $5^{\text {th }}$ larval stages. The survival rate varied from one instar larval to another. The sex ratio estimated (male / female) 
was 0.7 to 1.58 with an average of $1.03 \pm 0.33$ slightly in favor of males.

During the study period (July 2010 to June 2011), nine generations of $B$. occidentalis have been recorded continuously without a break. Larvae of $B$. occidentalis feed on the sap of the host plant and they produce droppings in the form of small bubbles and large amounts of honeydew (Figure 2). This damage contributes to the degeneracy of the eucalypts trees.

\section{DISCUSSION}

During the study period, in nursery, from July 2010 to June 2011, 9 generations of psyllid, $B$. occidentalis were identified. Our observations on the same species are different from the results obtained during the surveys in eucalyptus plantation where 5 or 6 generations were identified in the Yaounde locality (Soufo and Tamesse, 2015). The availability of young leaves all over the year on young plants could explain the increased number of generations during this study. Young leaves are mostly used by the female of $B$. occidentalis to lay their eggs and are suitable for larval development (Tamesse and Messi, 2002). This number of generations is approximate to that obtained by Tamesse and Messi (2004) for the citrus psyllid Trioza erytreae. The number of generations of $B$. occidentalis recorded is different from the one recorded for Pseudophacopteron spp., psyllid of Dacryodes edulis that showed 4 generations in Yaounde (Nsangou and Tamesse, 2014).

The study of the biological parameters of this species allowed us to better understand the biology of this important pest of Eucalyptus in our region. Mating lasts an average of 42 minutes. This result is similar to mating time for Ctenarytaina spatulata obtained by Santana and Zanol (2006); these authors recorded during their studies 44 minutes. The average time before eggs laying was 8 days and this is close to the work done by Abdullah (2008) on the potato psyllid Batericera cockerelli where the average time before laying is 6.9 days. Females of $B$. occidentalis laid on shoots, young leaves, young twigs and bracts. Those eggs laying sites are similar to those observed for psyllids C. spatulata (Santana and Zanol, 2006), C. thysanura (Mensah and Madden, 1993), C. eucalypti (Pinzon et al., 2002), Phytolyma fusca (Noubissi et al., 2016), P. eastopi (Nsangou, 2018), T. erytreae and Mesohomotoma tessmanni (Tamesse, 2005). The average longevity is 11 days for $B$. occidentalis; this duration is lower than that found by Santana and Zanol (2006) for $C$. spatulata (20 days) and Noubissi (2017) for $P$. fusca (16 and 18 days for males and females respectively), $D$. eastopi (15 and 17 days for males and females). It is different to that found by Aléné et al. (2005) for the psyllid Diclidophlebia xuani (29 days for females and 7 days for males),
Nsangou (2018) for the psyllid $P$. pusillum (12 and 15 days for males and females respectively) and $P$. eastopi (16 and 19 days for males and females respectively).

The average fertility is 38 eggs. These results are similar to those obtained by Mensah and Madden (1993) for $C$. thysanura (30 eggs) and by Nsangou (2018) for $P$. pusillum (31.25 eggs); it is different from $D$. xuani (532 eggs) recorded by Aléné et al. (2005); D. eastopi (372 eggs), D. harrisoni (171 eggs), $P$. fusca (52 eggs) recorded by Noubissi (2017). They are higher than those of Psyllopsis repens, psyllid of Fraxinus angustifolia, F. excelsior, $F$. ornus (11 to 16 eggs) observed by Malenovsky and Dusanka (2011); P. eastopi (21.44 eggs) recorded by Nsangou (2018). The full developmental time was between 27 and 40 days with an average of 32 days. These results are similar to those obtained on Diclidophlebia xuani (between 22 and 41 days with an average of 31.87 days) by Aléné et al. (2005); citrus psyllid Diaphorina citri (Tsai and Liu, 2000) ranging from 31.6 to 34.1 days; psyllid of $E$. clitoriae (33.7 days on average) described by Manoel et al. (2005); $D$. eastopi and $P$. fusca (31 days for males and 34 days for females) described by Noubissi (2017); $P$. pusillum (between 23 and 59 days with an average of 35.73 days) and $P$. eastopi (between 24 and 67 days with an average of 42.16 days) recorded by Nsangou (2018). The duration of the life cycle of $B$. occidentalis are longer than those obtained on $D$. harrisoni (25 days for males and 29 days for females) by Noubissi (2017). The survival rate of this species increases with the evolution of larval stages. The incubation which is embryonic development lasts on average $10.11 \pm 1.05$ days with a minimum value of 5 days and a maximum value of 13 days. These results are different from those obtained by Tsai and Liu (2000) who showed an incubation of 4.1 to 4.2 days in $D$. citri and approached those obtained by Manoel et al. (2005), Malenovsky and Dusanka (2011) who showed an incubation of 7.6 days in E. clitoriae and 7 to 10 days in Psyllopsis repens. This time allowed the $1^{\text {st }}$ larval stage been formed. The $1^{\text {st }}$ larval stage I required 3 to 6 days and averaged $3.78 \pm 0.67$ days to become the $2^{\text {nd }}$ larval stage. The $2^{\text {nd }}$ larval stage took 3 to 6 days to become the $3^{\text {rd }}$ larval stage with an average of $3.67 \pm 0.50$ days. The $3^{\text {rd }}$ larval stage lasted 3 to 6 days with an average of $3.56 \pm 0.53$ days to become the $4^{\text {th }}$ larval stage. The $5^{\text {th }}$ larval stage took 7 days with an average of $4.0 \pm 0.71$ days, to become the $5^{\text {th }}$ larval stage. The fledging occurs 3 to 8 days, with an average of $4.67 \pm 1.22$ days after the last instar larvae. These results are similar to those obtained by Manoel et al. (2005) where they showed that the duration of each larval stage is $5.7 ; 4.5 ; 4.8$; 5.0 and 6.1 days respectively for larval stage I, II, III, IV and V. The life cycle of $B$. occidentalis is 
shorter $(31.78 \pm 3.73$ days $)$ than that of Ctenarytaina spatulata which a mean of $44.89 \pm$ 1.187 days with $7.0 \pm 0.408$ days of incubation (Santana and Zanol, 2006).

The survival of the eggs of $B$. occidentalis $(67.48 \%)$ is similar to that found by Abdullah (2008) for the psyllid Bactericera cockerelli $(62.7 \%)$. The sex ratio is $1 / 1.03$ for $B$. occidentalis. This value is more of the double obtained by Manoel et al. (2005) for the psyllid E. clitoriae $(0.5)$ and is similar to that obtained for $D$. eastopi (1/1.04) by Noubissi (2017). This result differs to that found by Nsangou (2018) for psyllid P. Pusillum (1/1.15) and $P$. eastopi (1.05/1); Noubissi (2017) for $P$. fusca (1.08/1) and $D$. harrisoni $(1.09 / 1)$. The biology of the various species of psyllids is related to the phenology of the host plant, in direct relationship to the climatic factors. The presence of the young buds and sheets attracts the psyllids and is the proof of an abundance of food. This food is regarded as a limiting factor on the growth parameters.

\section{Conclusion}

The study of the biology of $B$. occidentalis, psyllid of the eucalyptus shows that this species is multivoltine, and its populations can be observed throughout the year without interruption. Mating lasts an average of 42 minutes. It completes its life cycle in 32 days on average. The first eggs are observed 5 days after fledging. These eggs are laid on buds, bracts, young leaves and twigs. Therefore, an average of 11 days is required for incubation of eggs and 11 days on average for adults of this pest, and the sex ratio is 1.03 . The biology of $B$. occidentalis, significant pest of the eucalyptus is known in the agro-climatic zone of the forest with bimodal precipitations. This study is our contribution for a biological/ an integrated pest management against $B$. occidentalis in Cameroon.

\section{REFERENCES}

1. Abdullah, N.M.M. (2008). Life history of the potato psyllid Bactericera cockerelli (Homoptera : Psyllidae) in controlled environment agricluture in Arizona. Afri. J. of Agri. Res. 3 (1): 60-67.

2. Aléné, D.C., Messi, J. and Quilici, S. (2005). Quelques aspects de la biologie de Diclidophlebia xuani (Hemiptera : Psyllidae), ravageur de Ricinodendron heudelotii Baill. (Euphorbiaceae) au Cameroun. Fruits. 60: 279-287. Doi 10.1051/fruits:2005034

3. Bonnemaison, L. and Missonier, J. (1956). Les psylles du poirier (Psylla pyri L.). Morphologie et Biologie. Méthodes de lutte. Annale d'Épiphytopathologie, 7 (2) : 263-331.

4. Bouvet, J.P.R., Harrand, L. and Burckhardt, D. (2005). Primera cita de Blastopsylla occidentalis y Glycapis brimblecombei (Hémiptera: Psyllidae) para la republica Argentina. Revista de la Sociedad Entomologica Argentina, 64 (1-2): 99-102.

5. Burckhardt, D. and Misfud, D. (1998). Psylloïdea
(Insecta: Hémiptera) of Arabian peninsula. Fauna of Arabia, 17: 7-43.

6. Chireceanu, C. and Fătu, V. (2012). On the Hawthorn Psyllid Cacopsylla melanoneura (Förster) Populations in Southeast Romania. Ecol. Balk., 4: 43-49.

7. Doran, J.C. and Wongkaeu, W. (1997). Eucalyptus camadulensis Dehnh. In: Faridah Hanum, I.2 Van der Maesen, L.J.G. (Editors). Plants ressources of southwest Asia $N^{\circ} 11$. Auxiliary plants. Backhuys publishers, Leiden, the Netherlands, pp 134-389.

8. Goolsby, J.A., Adamczyk,J.J., Crosslin, J.M., Troxclair, N.N., Anciso, J.R., Bester, G.G., Bradshaw, J.D., Bynum, E.D., Carpio, L.A., Henne, D.C., Joshi, A., Munyaneza, J.E., Porter, P., Sloderbeck, P.E., Supak, J.R., Rush, C.M., Willett, F.J., Zechmann, B.J. and Zens, B.A. (2012). Seasonal Population Dynamics of the Potato Psyllid (Hemiptera: Triozidae) and Its Associated Pathogen "Candidatus Liberibacter Solanacearum" in Potatoes in the Southern Great Plains of North America. J. Econ. Entomol., 105: 1268-1276. https://doi.org/10.1603/EC11435

9. Hodkinson, I.D. (1974). The biology of the Psylloïdea (Homoptera): a review. Bull. Entomol. Res., 64:325339

10.Hodkinson, I.D., (2009). Life cycle variation and adaptation in jumping plant lice (Insecta: Hemiptera: Psylloidea): a global synthesis. J. Nat. Hist., 43 (1-2): 65-179. https://doi.org/10.1080/00222930802354167

11.Ledoux, A. (1955). Observations sur la biologie de Phytolima lata Scott var. fusca, Psylloidea gallicole sur l'iroko (Chlorophora excelsa). Ann. Sci. Nat. Zoo., 11: 291-310.

12.Malenovsky, I. and Dušanka, J.P. (2011). A revised description of Psyllopsis repens Loginova, 1963 (Hemiptera: Psylloidea: Psyllidae), with first records from Europe. Arch. Biol. Sci., 63 (1): 275-286. DOI:10.2298/ABS1101275M

13.Manoel, G.C.G.J., Reginaldo, B., Fernando, R.S. and Geraldo, J.N.V. (2005). Occurrence and biological aspects of the clitoria tree psyllid in Brazil. J. Agri. Sci., 62 (3): 281-285. http://dx.doi.org/10.1590/S0103 $-90162005000300012$

14.Mensah, R.K. and Madden, J.L. (1993). Life history and biology of Ctenarytaina thysanura Ferris and Klyver (Hemiptera : Psyllidae) on Boronia megastigma Nees ex Bartl. (Rutaceae) in Tasmania. Aust. J. Entomol. Soc., 32 : 327-337.

15.Messi, J. (1984). Biologie et Ecologie de Mesohomotoma tessmanni (Homoptera ; Psyllidae), ravageur du cacaoyer. Thèse de Doctorat d'Etat, Université Paul Sabatier, Toulouse, France, $188 \mathrm{p}$.

16.Noubissi, Youmbi, E.D. (2017). Biologie des psylles (Hemiptera: Psylloidea) ravageurs de Milicia excelsa Wehw C. C. Berg (Moraceae) et Triplochiton scleroxylon K. Schum (Malvaceae) au Cameroun. Thèse de Doctorat/PhD, Université de Yaoundé I, Cameroun, $127 \mathrm{p}$.

17.Noubissi, Youmbi, E., Yana, W. and Tamesse, J.L. (2014). Population Dynamic of Diclidophlebia eastopi Vondracek and Diclidophlebia harrisoni Osisanya, Psyllids Pest of Triplochiton scleroxylon (K. schum) (Urticales: Sterculiaceae) in Yaounde, Cameroon. J. Entomol., 11(4): 182-197.

18.Noubissi, Youmbi, E., Yana, W. and Tamesse, J.L. (2016). Population Dynamic of Phytolyma fusca Alibert (Hemiptera; Homotomidae) psyllids pest of Miliceae excelsa (Welw) (Rosales: Moraceae) in 
Cameroon. J. Entomol., 4(6): 256-262.

19.Nsangou, M.I. (2018). Biologie, dynamique et taxonomie des psylles (Hemiptera : Phacopteronidae) inféodés à Dacryodes edulis (Burseraceae) et taxonomie du psylle de Zanthoxylum gilletti (Rutaceae) au Cameroun. Thèse de Doctorat/PhD, Université de Yaoundé I, Cameroun, 237p.

20.Nsangou, M.I. and Tamesse, J.L. (2014). Populations dynamic of Pseudophacoteron spp. (Hemiptera: Phacopteronidae), psyllids pest of Dacryodes edulis (Burseraceae) in Cameroon. I. J. A. A. R., 5(1):56-73

21.Osisanya, E.O. (1974). Aspect of biology of Diclidophlebia eastopi Vondracek and $D$. harrisoni Osisanya (Homoptera: Psyllidae). Bull. Entomol. Res., 64: 9-17.

22.Pinzón, F.O.P., Guzmán, C.M. and Navas, N.F. (2002). Contribución al conocimiento de la biología, enemigos naturales y daños del pulgón del eucalipto Ctenarytaina eucalypti (Homoptera: Psyllidae). Revista Colombiana de Entomología, 28: 123-128.

23.Santana, D.L.Q. and Zano,I K.M.R. (2006). Biologia de Ctenarytaina spatulata Taylor, 1997 (Hemiptera, Psyllidae) em Eucalyptus grandis Hill ex Maiden. Acta Biologica Paranaense, 35: 47-62.

24.Soufo, L. and Tamesse, J.L. (2015). Population dynamic of Blastopsylla occidentalis Taylor (Hemiptera: Psyllidae), a psyllid pest of eucalypts. Neotr. Ent., 44 (5): 504-512. DOI 10.1007/s13744015-0304-7

25.Tamesse, J.L. (1996). Ecologie de Trioza erytreae (Del Guercio) (Homoptera : Psyllidae) psylle vecteur de la maladie du "verdissement des agrumes" du Cameroun. Thèse de doctorat de $3^{\text {ème }}$ cycle, Univer- sité de Yaoundé I, Yaoundé (Cameroun), 276p.

26.Tamesse, J.L. (2005). Contribution à l'étude de la biodiversité, de la taxonomie et de la biologie des psylles (Hemiptera : Psylloidea) du Cameroun. Thèse de Doctorat d'Etat, Université de Yaoundé I, Yaoundé, Cameroun. 285p.

27.Tamesse, J.L. and Messi, J. (2002). Incidence de Trioza erytreae (Del Guercio) (Homoptera : Triozidae), psylle vecteur du greening sur la croissance des plantules d'agrumes dans une pépinière au Cameroun. Insect Science and Application, 22 (2): 97-103. DOI: 10.1017/S1742758400015174

28.Tamesse, J.L. and Messi, J. (2004). Facteurs influençant la dynamique des populations du psylle africain des agrumes Trioza erytreae Del Guercio (Hemiptera: Triozidae) au Cameroun. Int. J. Trop. Insect. Sci., 24 (3): 213-227. DOI: 10.1079/ IJT200429

29.Teck, S.L.C., Abang, F., Beattie, A., Heng, R.K.J and Wong, S.K. (2011). Seasonal Population Dynamics of the Asian Citrus Psyllid, Diaphorina citri Kuwayama in Sarawak. Am. J. Agri. Biol. Sci.,6:527-535

30.Tsai, J.H. and Liu, Y.H. (2000). Effects of temperature on biology and life table parameters of the Asian citrus psyllid, Diaphorina citri Kuwayama (Homoptera: Psyllidae). Ann. Appl. Biol., 137 (3): 201-206. DOI:10.1111/j.1744-7348.2000.tb00060.x

31.White, M.G. (1964). Research in Nigeria on the iroko gall bug (Phytolyma sp.): Being a report to the director of forest research on investigation on gall bug (Phytolyma sp.) injury to iroko tree (Chlorophora sp.). Nig. F. Inf. Bull., 18: 1-12. 